\title{
CONTRIBUTIONS TO THE STUDY OF THE ALLUVIAL GOLD FROM VALEA PIANULUI AREA (ALBA DISTRICT)
}

\author{
BEDELEAN HOREA ${ }^{1}$, BEDELEAN AURA ${ }^{1}$
}

\begin{abstract}
Contributions to the Study of the Alluvial Gold from Valea Pianului Area (Alba District). Pianu de Sus area (Alba district) is located in the north-eastern part of the Sebeş Mountains. The region consists of metamorphic (Sebeş-Lotru group), magmatic (granites and quartziferous porphyries and pegmatites) and sedimentary deposits (Senonian, Neogene and Quaternary age). Granulometric studies, separations of the heavy fractions, optic and electronic microscopic investigations were performed on the alluvial deposits and detritic sedimentary formations. The analysed gold shows tipical morphology for two grains types: primary and secondary. From a chemical point of view was evidenced electron microprobe The chemical analyses, performed by using electron microprobe, shows a high amount of gold and silver.
\end{abstract}

KEY WORDS: alluvial gold, composition, morphology, Pianu de Sus

\section{Introduction}

Pianu de Sus area (Alba district) is located in the northern side of the Southern Carpathians, in the north-eastern part of the Sebeş Mountains. This area represents one of the oldest regions known for alluvial gold prospecting and exploration since the antiquity (Dacian-Roman times).

Previous researches in this area were performed by E. Bocec Saulea (1934 - 1935), Marincaş Valeria, (1965), Galcenco V., Veress E., Velciov Gh., (1995), Balaban A., Costea C., (1999).

Signs of the old works for alluvial gold can be found around Pianu de Sus village; gold used to be extracted by using rudimentary methods, followed by the traditional gold washing procedure.

This study presents some of our results in Pianu de Sus area obtained by a mixed research team (French-German-Romanian), consisting of a morphological characterization of the alluvial gold and of other minerals in the heavy fraction, as well as of the chemical composition of gold.

1 "Babeş-Bolyai" University, Department of Geology, 1, Kogălniceanu St., RO-3400 Cluj-Napoca, Romania 


\section{Methods and materials}

The sampling area was located in the middle course of Pianului valley, upstream and downstream from Pianu de Sus; samples were collected from the recent alluvia of Pianului valley and its effluents (Valea de Sebiş, Pârâul Stoii, Valea Hotarului, etc.), as well as from sedimentary geological formations. The sampling points were located at intervals of about 20-30 m and at the main and secondary joints.

In each sampling point samples of $10 \mathrm{~kg}$ raw detrital material (sand + pebbles) were collected. This material was concentrated - sieving, washing with the concentration trough ("şaitroc" -rom. ) - for collecting the gold lamellae (grains) which were subsequently investigated.

The microscopic investigations of the typical gold morphological aspects were performed in the laboratories of the Technische Universitat Munchen.

The laboratory work was focused on the whole range of minerals from the heavy fraction and they consisted in granulometric studies, separations of the heavy fractions, optic-microscopic investigations.

The gold-containing samples were studied in polished sections under the electron microscope for defining the morphometry of gold grains and understanding their source and genesis.

The morphoscopic investigation consisted in:

- the general morphology of the grains - the description and classification was done according to Herail (1984) into 8 categories: square, rectangular, circular, oval (and rhombic), spherical, trapezoidal, triangular, elongated.

- the shape of the border the grains: regular, quasi-regular, very irregular

- the shape of the margins of the grains: rounded and blunt, indented or showing changes of the direction, flipping.

- morphology of the surface of the grains, based on the general topography: broad depressionary areas, narrow depressionary areas, the presence of some mineral inclusions (non-metallic or accessory minerals), the presence of mechanic deformation patterns (striations, scratches, conchoidal traces of impact), transformation processes of the mineral assemblages (argillization, oxidation).

All the morphoscopic observations (except for the description of the general morphology) were performed on each side of the lamellae, by using the optical microscope.

The study under the electron microscope was realized for tracking the overprint of the secondary features, produced by transport (mechanical deformation, recrystallization) on the primary patterns. 
The chemical analyses were performed by using electron microprobe on 25 gold grains; the minor elements content and the composition of the inclusions were the main goals.

\section{Geology of the region}

From a geographic point of view, the studied region is located in the north-eastern part of Sebeş Mountains and SE from Mureş passageway. The region consists of magmatic, metamorphic and sedimentary deposits.

The metamorphic formations, which form the basement of the region, belong structurally to the Getic domain and lithologically to the Sebeş-Lotru group. Petrographically the following types can be found: meso- and epimetamorphic schists, migmatites, gneiss, paragneiss, quartzites, micaschists, amphibolites, quartzitic schists, quartzitic-sericitic schists etc.

The magmatic formations are scarce and consist of granites and quartziferous porphyries and pegmatites.

The sedimentary formations were transgressively overlaid on the crystalline basement and they belong to the Upper Cretaceous, the Neogene and the Quaternary.

The sedimentary deposits of the Upper Cretaceous (Senonian) form in Pianu de Sus area a strip oriented from east to west; they consist of conglomerates and sandstones. V. Marincaş (1965) separated two horizons: basal conglomerate and sandstone horizon, and the marls and clays with Inoceramus horizon.

The Neogene deposits are represented Egerian-Eggenburgian (sandstones, marls, sandy clays), Badenian (continental pebbles and clays in the basal part, followed by marls, clayey marls, clays, sandy clays, and sands), and Lower Sarmatian deposits (clays, marly clays interlayered with sands). The Quaternary deposits consist of terrace and alluvial deposits.

\section{Results}

The studied samples were collected from two effluents of Pianu valley (Valea de Sebiş and Hotarului valley).

The gold grains are generally isolated bodies, rarely being grouped as nuggets. The size of the analyzed grains ranges between $2 \times 2 \mathrm{~mm}$ and $0,08 \times 0,08 \mathrm{~mm}$.

Based on our results it can be mentioned that the samples contain two grain types: primary and secondary - being reworked during transport (the latter being quantitatively dominant) (PI. I- fig. 1, 2; PI. II-fig. 1, 2; PI. III, fig. 1). 


\section{Morphoscopic features:}

- the general shape of the primary gold lamellae is irregular, and angular. A great heterogeneity of morphologies can be noticed, from elongated to triangular, and rectangular. The secondary gold lamellae - which dominate - have a rounded shape.

- the borders of the grains are generally irregular and show frequently uneven surfaces, small depressions and hollows). Secondary gold shows regular, rounded borders.

- the shape of the margins is rounded, and blunt in case of secondary gold, but only rarely the margins are bended or flipped.

- the morphology of the surface of the grains is smooth and planar in case of secondary gold and irregular (with cavities) in case of primary gold. No crystallographic faces were noticed. Even in case of transport over large distance, very rarely striations could be noticed on the surface of the lamellae $(20-25 \%$ of the lamellae surfaces show mechanical striation) (PI. III, fig. 1).

- inclusions - the study under electron microscope showed the presence of mineral inclusions typical for the primary assemblages in the ore: quartz, feldspar, apatite, arsenopirite, galenite, monazite etc. (PI. 1-fig. 1, 2; PI. III, fig. 2).

Chemical data: were obtained on polished sections by the means of electron microprobe. A high content of $\mathrm{Au}(\approx 90 \%)$, and Ag was noticed (tab. 1).

This chemical composition is the result of levigation of $\mathrm{Ag}$, which under oxidizing conditions becomes soluble and thus a process of $\mathrm{Au}$ concentration takes place during the deposition of the sediments.

The semi-quantitative measurements show a chemical variability in each gold grain. All the lamellae have similar average $\mathrm{Au}$ and $\mathrm{Ag}$ contents, as well as similar $\mathrm{Fe}, \mathrm{As}, \mathrm{S}, \mathrm{La}, \mathrm{Ce}, \mathrm{O}, \mathrm{Pb}$, etc amounts. Certain minerals host these elements, such as: arsenopirite, galenite, monazite; they are present as mineral inclusions in the gold grains (PI. III, fig. 2; PI. IV, fig. 2).

\section{Conclusions}

The source of gold - the detrital gold lamellae clearly originate in the Cretaceous (Senonian) pebble banks. In general, the Cretaceous deposits in this part of Romania host gold (Sebeşului and Mureşului valleys). The main gold-rich samples were collected from sandstone epiclastic deposits of a grey-reddish color of a Senonian age.

The resulting morphology is the result of a fluviatile transport on large distances (>100km), and this gives birth to irregular and rounded shapes. 
The origin of this type of gold is not at all similar with that of the recent "gold alluvial ores". It is probably related to the old magmatic rocks or to the pegmatites, fact for which pleads the assemblage containing monazite and arsenopirite - which were identified by us in the heavy fraction and in the inclusions.

The gold particles preserve sometimes the primary features, both concerning the shape and the mineral inclusions.

\section{REFERENCES}

1. Balaban A., Costea C., (1999), The alluvial gold of romanian territory: a review of their morphology, geochemistry and sources, Abstract volume: "Mineralogy, Petrology, Metallogeny and Geochemistry International Symposium", An. Inst. Buc., Suppl. an. XLVIII, p. 2-3.

2. Bocec Saulea, E., (1934 - 1935), La constitution mineralogique du sable alluvial de Pianul de Sus (distr. Alba, Roumanie), An. Sci. Univ. Iaşi, tom. XXI, p. 514-523.

3. Herail G., (1984), Geomorphologie et gitologie de l'or detritique, Editions du CNRS, Paris, $756 \mathrm{p}$.

4. Galcenco V., Veress E., Velciov Gh., (1995), L'or alluvionaire du cours moyen des rivieres Mureş, Strei et Crişul Alb (Roumanie), Rom. J. Mineralogy, 76, 2, p. 105-110.

5. Marincaş Valeria, (1965), Studii geologice în regiunea Sebeş-CîlnicSăsciori-Răchita-Pianul de Sus-Cioara cu privire specială asupra depozitelor cretacice" - Teza de doctorat, Univ. Bucureşti. 


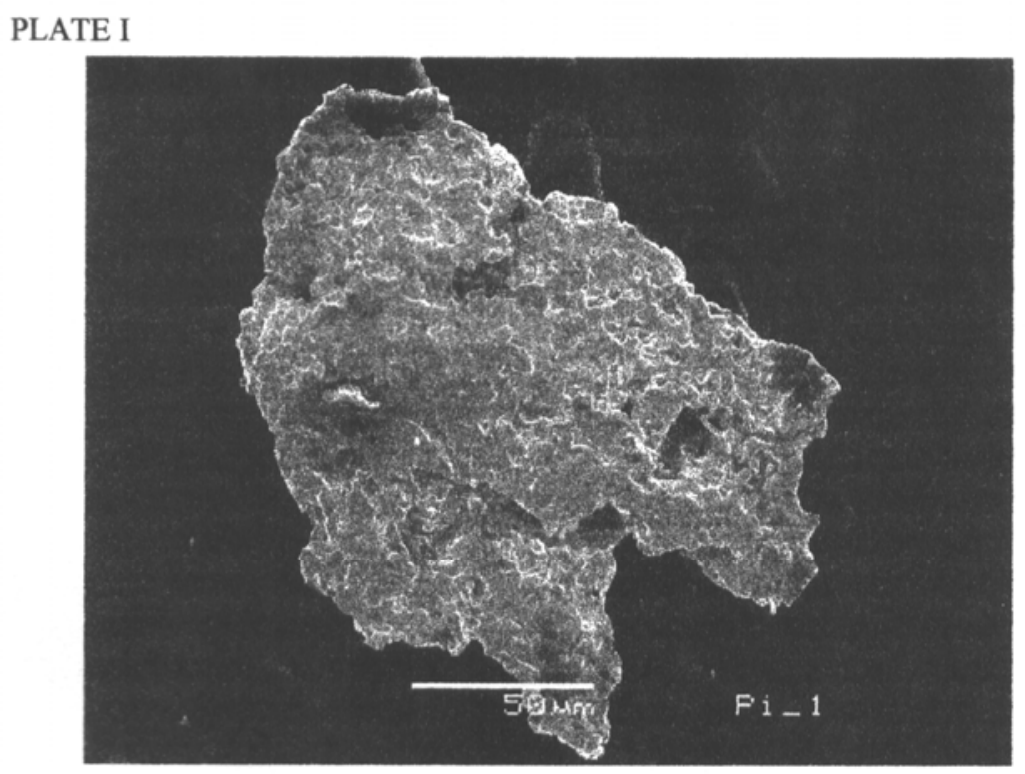

Fig. 1

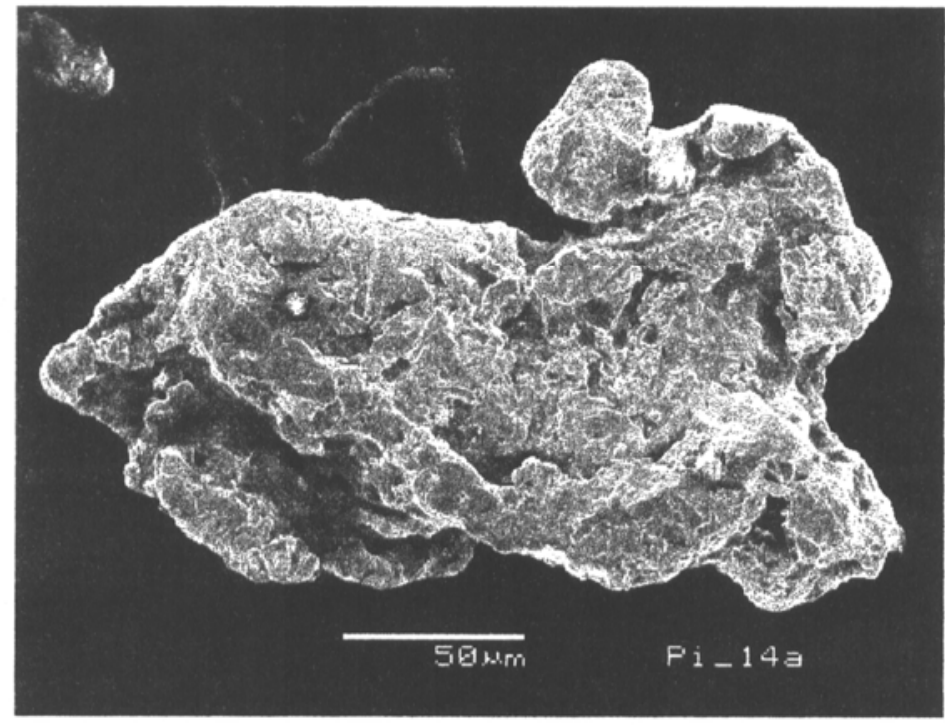

Fig. 2

Plate I - fig. 1, 2 - Grains of primary gold from Valea de Sebiş (Alba district) 


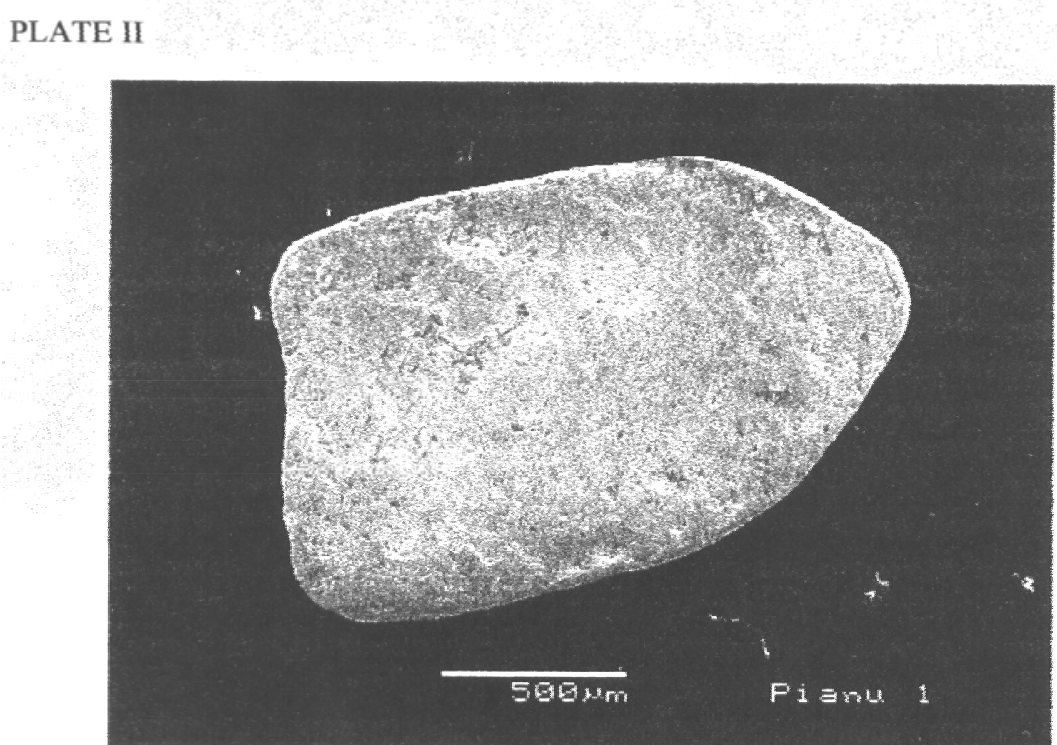

Fig. 1

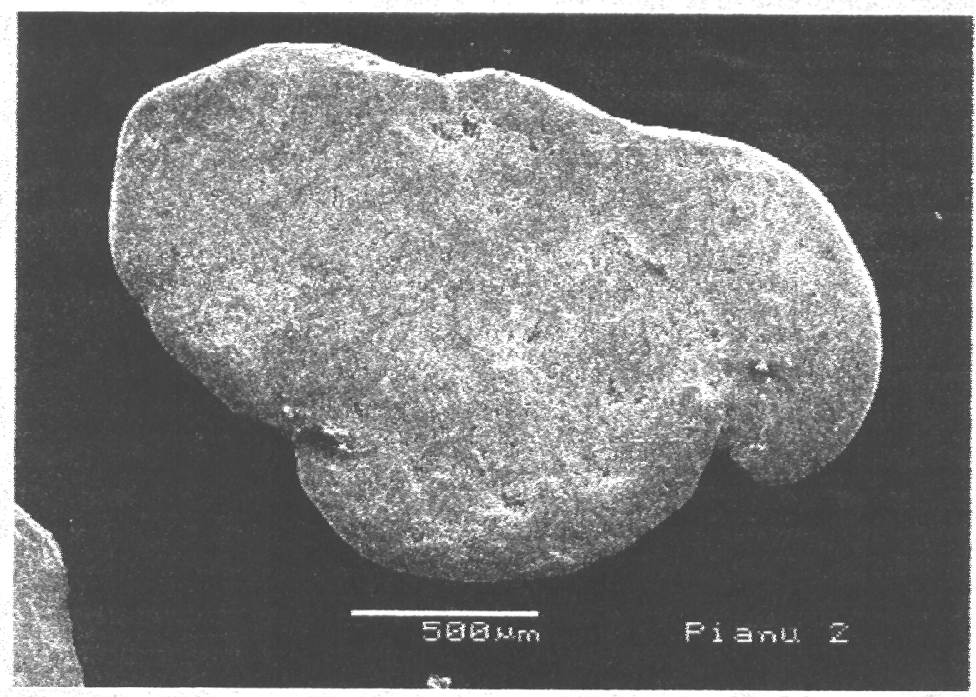

Fig. 2

Plate II - fig. 1, 2 - Grains of secondary gold from Valea de Sebiş (Alba district) 


\section{PLATE III}

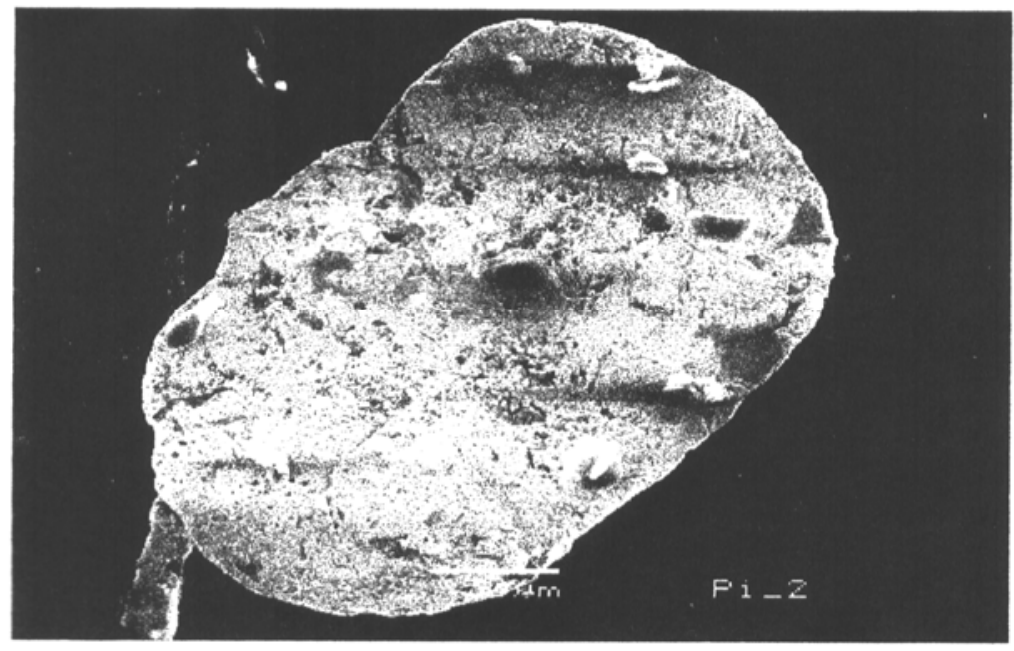

Fig. 1

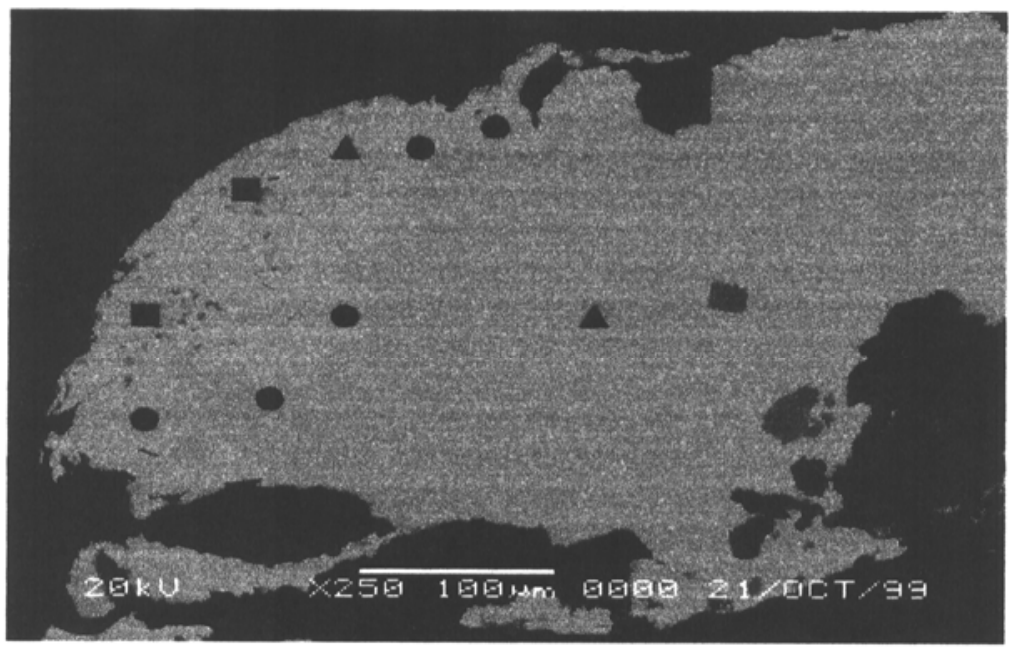

Fig. 2

Plate III - fig.1 - Grain of secondary gold from Valea Hotarului (Alba district) fig.2 - SEM image of gold grain (polished section) from Valea de Sebiş (Alba district) (see tab.1) • = Au-Ag; $\quad v$ = galenite; $\sigma=$ arsenopirite 
PLATE IV

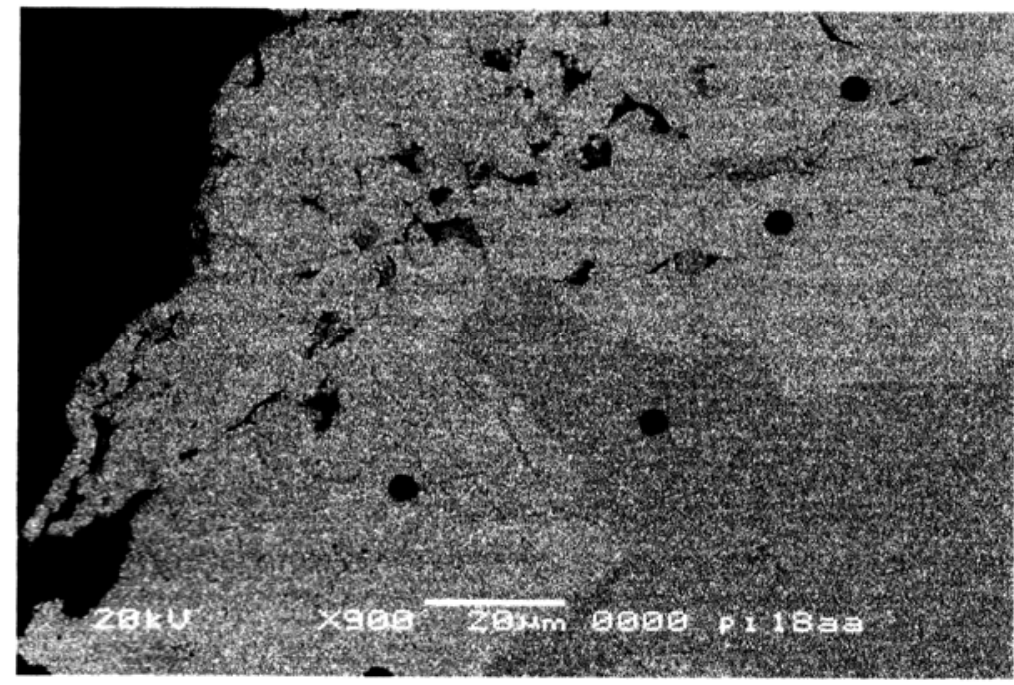

Fig. 1

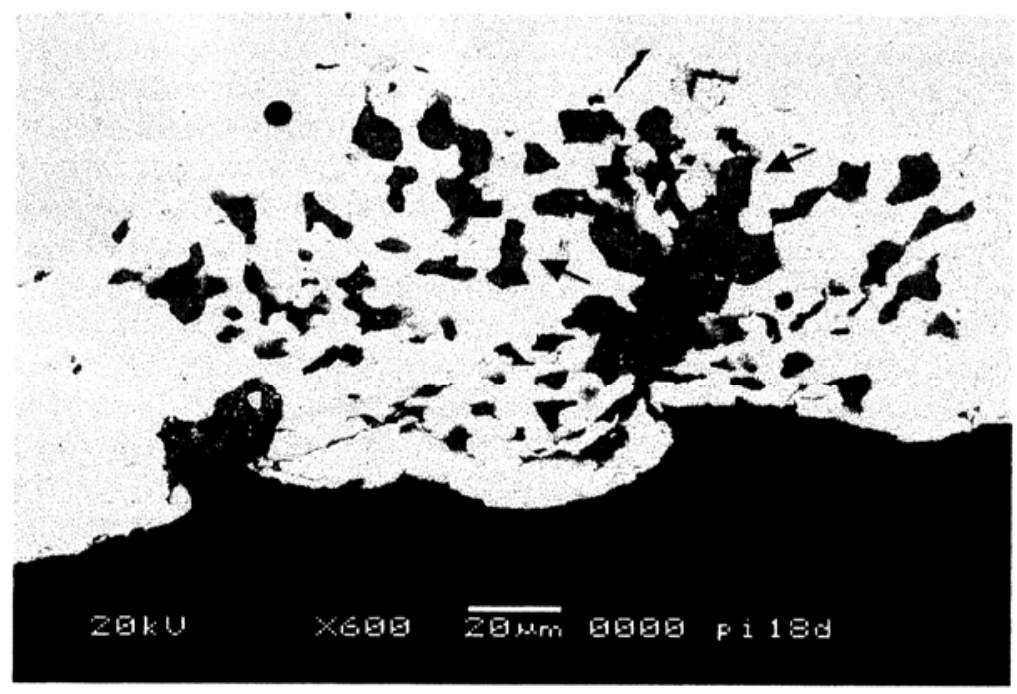

Fig. 2

Plate IV - Fig. 1, 2 - SEM images of gold grains (polished sections) from Valea de Sebiş (Alba district) (see tab. 1) • =Au-Ag; =monazite 